\title{
Absorption Decontamination of Radioactive Waste Solvent by Activated Alumina and Bauxites
}

by

N. M. Hassan

Westinghouse Savannah River Company

Savannah River Site

Aiken, South Carolina 29808

J. C. Marra

Westinghouse Savannah River Company

SC USA

DOE Contract No. DE-AC09-89SR18035

This paper was prepared in connection with work done under the above contract number with the U.S.

Department of Energy. By acceptance of this paper, the publisher and/or recipient acknowledges the U.S. Government's right to retain a nonexclusive, royalty-free license in and to any copyright covering this paper, along with the right to reproduce and to authorize others to reproduce all or part of the copyrighted paper.

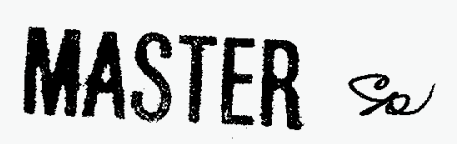




\section{DISCLAIMER}

This report was prepared as an account of work sponsored by an agency of the United States Government. Neither the United States Government nor any agency thereof, nor any of their employees, makes any warranty, express or implied, or assumes any legal liability or responsibility for the accuracy, completeness, or usefulness of any information, apparatus, product, or process disclosed, or represents that its use would not infringe privately owned rights. Reference herein to any specific commercial product, process, or service by trade name, trademark, manufacturer, or otherwise does not necessarily constitute or imply its endorsement, recommendation, or favoring by the United States Government or any agency thereof. The views and opinions of authors expressed herein do not necessarily state or reflect those of the United States Government or any agency thereof.

This report has been reproduced directly from the best available copy.

Available to DOE and DOE contractors from the Office of Scientific and Technical Information, P.O. Box 62, Oak Ridge, TN 37831; prices available from (615) 576-8401.

Available to the public from the National Technical Information Service, U.S. Department of Commerce; 5285 Port Royal Road, Springfield, VA 22161. 


\section{DISCLAIMER}

Portions of this document may be illegible in electronic image products. Images are produced from the best available original document. 


\section{ADSORPTION DECONTAMINATION OF RADIOACTIVE WASTE SOLVENT BY ACTIVATED ALUMINA AND BAUXITES}

by

Neguib M. Hassan ${ }^{*}$, James C. Marra, and Edward A. Kyser

WESTINGHOUSE SAVANNAH RIVER CO.

SAVANNAH RIVER TECHNOLOGY CENTER

P.O. BOX 616, AIKEN, SOUTH CAROLINA 29802

* To whom correspondence should be directed 


\begin{abstract}
An adsorption process utilizing activated alumina and activated bauxite adsorbents was evaluated as a function of operating parameters for the removal of low level radioactive contaminants from organic waste solvent generated in the fuel reprocessing facilities and support operations at Savannah River Site. The waste solvent, $30 \%$ volume tributyl phosphate in nparaffin diluent, was degraded due to hydrolysis and radiolysis reactions of tributyl phosphate and n-paraffin diluent, producing fission product binding degradation impurities. The process, which has the potential for removing these activity-binding degradation impurities from the solvent, was operated downflow through glass columns packed with activated alumina and activated bauxite adsorbents. Experimental breakthrough curves were obtained under various operating temperatures and flow rates. The results show that the adsorption capacity of the activated alumina was in the order $10^{4} \mathrm{dpm} / \mathrm{g}$ and the capacity of the activated bauxite was $10^{5} \mathrm{dpm} / \mathrm{g}$. The performance of the adsorption process was evaluated in terms of dynamic parameters (i.e. adsorption capacity, the height and the efficiency of adsorption zone) in such a way as to maximize the adsorption capacity and to minimize the height of the mass transfer or adsorption zone.
\end{abstract}




\section{INTRODUCTION}

The Purex process has been widely used for reprocessing of irradiated nuclear fuel elements. The process is based on multistage countercurrent solvent extraction to separate uranium $(\mathrm{U})$ and plutonium $(\mathrm{Pu})$ from fission products. The $\mathrm{U}$ and $\mathrm{Pu}$ are extracted into an organic phase (30\% tributyl phosphate by volume in n-paraffin diluent), leaving the bulk of the fission products in the aqueous raffinate. It was widely recognized (1-4) that the tributyl phosphate (TBP) and the n-paraffin diluent are degraded due to hydrolytic and radiolytic reactions, forming activity-binding degradation products that can cause product losses, poor separation efficiencies, and emulsions which could interfere with the process operations. The primary degradation products (i.e. monobutyl phosphate, dibutyl phosphate, phosphoric acid, and butanol) were produced from the hydrolytic and dealkylation reactions of the tributyl phosphate when contacted with nitric acid at relatively high temperatures. The secondary degradation products (nitroparaffins, aldehydes, ketones, and carboxylic acids), on the other hand, were originated from the radiolytic reactions of the n-paraffin diluent when exposed to intensive radiation. In Purex process, the spent solvent is continuously regenerated by scrubbing with sodium carbonate, sodium hydroxide, phosphoric acid, and/or potassium hydroxide solutions after each pass through the process and most of the radioactivity belonging to primary degradation products are removed. Residual activity due to secondary degradation products, however, cannot be removed by these washing solutions as these long-chain soluble organic compound tend to remain in the solvent even after scrubbing with carbonate washing solutions to again 
complex fission products when the solvent is recycled. Thus, other methods (5-6) have been used to remove some of these products, thus producing nparaffin diluent with a low level radioactivity and a residue of tributyl phosphate origin. Although such methods as vacuum distillation, steam stripping, and flash vaporization techniques are effective, they are limited by the maximum allowable distillation temperature that could lead to significant decomposition of the TBP tar residues. Several investigators (7-8) have studied an adsorption-based cleanup process to improve recycle solvent performance. These studies have shown that solid adsorbents such as activated alumina and base-treated silica gel have the potential for removal of some of the activity-binding degradation products.

For the final disposal of the waste solvent, several options are available including the separation of the tributyl phosphate and the activity-binding degradation products from the n-paraffin diluent, followed by incineration of the diluent and chemical destruction of the tributyl phosphate. The objective of this work was to evaluate an adsorption process utilizing activated alumina and activated bauxite for decontamination of radioactive waste solvent from Purex process. The effects of temperature and flow rate on the process performance were investigated. The process dynamic parameters, such as adsorption capacity and the height and efficiency of the adsorption zone were calculated from experimental breakthrough curves. Thermogravimetric analysis were performed to determine the thermal stability of fresh and spent activated alumina and bauxite samples. 


\section{EXPERIMENTAL SECTION}

\section{Materials}

The adsorbents used in this study were activated alumina, Type A-2, supplied by La Roche Chemicals and activated bauxite, Type RI, provided by Engelhard Chemical Co. The activated alumina was produced from relatively high purity aluminum hydroxide by controlled heating to eliminate most of the water of hydration. Activated bauxite was produced by thermal activation of bauxite containing alumina in the form of gibbsite. The major oxide contents of these adsorbents were $\mathrm{Al}_{2} \mathrm{O}_{3}, \mathrm{SiO}_{2}, \mathrm{Fe}_{2} \mathrm{O}_{3}$, and $\mathrm{TiO}_{2}$. The physicochemical properties of the adsorbents are shown in Table 1.

The solvents used in this study were radioactively contaminated $\mathrm{TBP} / \mathrm{n}$-paraffin waste generated from the fuel reprocessing facilities and support operations at Savannah River Site. The "as received" solvents from different facilities were composed of $30 \%$ volume tributyl phosphate in $\mathrm{C}_{11^{-}}$$\mathrm{C}_{16}$ n-paraffin diluent (see Table 2). The solvents were extensively degraded and discolored during contact with certain aqueous solutions in fuel reprocessing facilities. The discoloration was due to the presence of longchain organic degradation products that originated from hydrolysis and radiolysis reactions of TBP and n-paraffin diluent. A number of analyses (liquid scintillation counting, alpha plate counting, and alpha pulse height analysis) were performed prior to use of each solvent to determine its gross alpha activity and the type of nuclides present.

\section{Apparatus and Procedure}

Experimental apparatus for measuring adsorption breakthrough curves of activity-binding degradation products was shown in Figure 1. The 
measurements of experimental breakthrough curves were performed with two glass columns: a smaller column, $13 \mathrm{~mm}$ in diameter, was employed to conduct experiments with activated alumina and a larger column, $25 \mathrm{~mm}$ in diameter, was used with the activated bauxite. The smaller column was usually packed with $20 \mathrm{~g}$ of alumina whereas the larger column was packed with approximately $60 \mathrm{~g}$ of bauxite. The total bed heights were $43 \mathrm{~cm}$ and 23 $\mathrm{cm}$ for the $13 \mathrm{~mm}$ and $25 \mathrm{~mm}$ diameter columns, respectively. Special care was taken when packing the columns to ensure that the same amount of adsorbent was used per unit length. Prior to each run, the adsorbent was regenereated in the column at $180{ }^{\circ} \mathrm{C}$ for 6 hours. After regeneration, the column was allowed to cool to the desired adsorption temperature and a radioactively contaminated solvent was pumped from a feed flask at constant flow rate and introduced from the top of the column to avoid fluidization or expansion of the bed. Decontaminated effluent samples were collected from the bottom of the column at equal time intervals using a continuous sampling system. The adsorption run was continued until the bed becomes exhausted as indicated by the changing color of effluent samples which become increasingly yellowish as complete beakthough was approached. After adsorption was completed, the solvent feed remaining in the bed was drained from the bottom of the column and a small adsorbent sample was removed form the bed for thermogravimetric analysis. The spent adsorbent bed was slowly heated while under vacuum to drive off residual volatile material. The dry spent bed was finally removed from the column and packed for disposal. All experiments were performed under near isothermal conditions by controlling the temperature of the surface of the column. 


\section{Thermogravimetric Analysis (TGAs)}

TGA experiments were performed using a TA Instruments Model 951 thermogravimetric analyzer (TA Instruments, Wilmington, DE) coupled with 2100 thermal analyzer. The unit was installed in a radioactive glovebox and calibrated with "standard" calcium oxalate monohydrate sample, whose weight loss curves as a function of temperature was known. The TGA curve

of the "standard" was used to verify proper temperature calibaration and stable instrument operation. After calibration, a clean sample was loaded onto the balance arm and tared by electronic suppression. A small sample, 10 to 28 mg, was then loaded onto the sample pan and allowed to reach a steady weight at ambient conditions. The sample was heated from room temperature to $1000{ }^{\circ} \mathrm{C}$ at a rate of $10{ }^{\circ} \mathrm{C} / \mathrm{min}$, and held at $1000{ }^{\circ} \mathrm{C}$ for 1 minute. The TGA curve so obtained was used to calculate the percent weight changes in different temperature regions.

\section{Solvent Analysis and Activity Measurement}

Three types of analyses, namely liquid scintillation counting, alpha plate counting, and alpha pulse height analysis (PHA), were performed with radioactively contaminated feed solvents to determine their gross activity. The liquid scintillation counting (LSC) was used to provide estimates of the residual alpha and beta activities in decontaminated effluent samples. The analysis was performed with Packard Tricarb liquid scintillation counters (Model 2550AB and 2250AC). The samples were properly prepared (i.e. correct volume, cocktail, and vials were chosen) and the gross alpha/beta counting prorocol of the instrument was set up to provide the alpha and beta counts in the samples. The sample activity $(\mathrm{dpm} / \mathrm{ml})$ was calculated using the 
net count rate, sample dilution factor, and an average alpha/beta-particle detection efficiency. The precision of this method was found to be $\pm 5 \%$ at the $95 \%$ confidence level.

The alpha plate counting was used with feed solvents containing significant quantities of alpha/beta activity. A small sample was mounted directely on a metal plate or a dish and the liquid was evaporated under a heat lamp until it was completely dry. The gross alpha activity on the plate was measured with a gas flow proportional counter; the beta activity was measured with a Geiger-muller probe. The sample activity $(\mathrm{dpm} / \mathrm{ml})$ was calculated from the net count rate of alpha particles, the counting efficiency as determined from an NBS electroplate standard, and the volume of the sample. A precision of $\pm 3 \%$ was normally obtained on duplicate alpha plate counting.

The alpha pulse height analysis (PHA) was used to determine the relative count rates of nuclides present within the feed solvent. An alpha spectrophotometer, Model Tennelec TC 256, coupled to a Canberra Series 85 Multichannel analyzer and associated electronics, along with a $\mathrm{Si}(\mathrm{Au})$ solid state surface barrier detector, was used for the alpha PHA measurements. The absolute count rate determined from the gross alpha detector was used in conjunction with the relative percentages of the nuclides present as determined from PHA to ascertain the absolute amount of any alpha emitting nuclide present.

\section{Theory of Dynamic Adsorption}

Mathematical expressions relating dynamic parameters for adsorption to experimental breakthrough curves were used to characterize the adsorption process. The process dynamic parameters studied in this work were the 
adsorption capacity and the height and efficiency of the adsorption zone. The adsorption zone is a relatively narrow mass transfer band at the top of the bed, where the activity-binding degradation products are initially adsorbed. This zone moves downward through the bed as the solvent flow continues from the top the column and eventually reach the bottom, where the activitybinding degradation products start to break through the column and momentarily appear in the effluent. As the solvent flow continues to the column, the adsorption zone is forced out of the bed and the activity of the effluent samples rapidly approachs that of the feed solvent; the adsorbent bed is considered to be near saturated. The height of the adsorption zone $\left(h_{\mathrm{Z}}\right)$ is calculated from the equation by Michael (9)

$$
h_{z}=L_{o}\left[\frac{\left(t_{e}-t_{b}\right)}{\left(t_{e}-(1-F)\left(t_{e}-t_{b}\right)\right)}\right]
$$

where $\mathrm{L}_{\mathrm{o}}$ is the height of adsorbent bed, $\mathrm{t}_{\mathrm{b}}$ is the breakthrough time, $\mathrm{t}_{\mathrm{e}}$ is the bed exhaustion time, and $\mathrm{F}$ is the fraction of the bed that is still capable of adsorbing. The parameter, $\mathrm{h}_{\mathrm{z}}$, is related to the efficiency of the adsorption zone according to the equation

$$
\gamma=\frac{\left(L_{o}-F h_{z}\right)}{L_{o}} 100
$$

The adsorption capacity is determined from the experimental breakthrough using the equation

$$
q_{n}=\frac{Q C_{o}}{m} \int_{t_{b}}^{t} e\left(1-C_{t} / C_{o}\right) d t
$$

where $\mathrm{Q}$ is volumetric flow rate, $\mathrm{Co}$ is the initial activity of the solvent, $\mathrm{C}_{\mathrm{t}}$ is the activity of the effluent sample at time $t, m$ is the mass of adsorbent. The 
integral in eq. (3) represents the total area behind the breakthrough curve. The performance of the adsorption decontamination process was evaluated in such a way as to minimize the height of the adsorption zone and to maximize the adsorption capacity.

\section{RESULTS AND DISCUSSION}

Thermogravimetric Analysis: Results of the thermogravimetric studies of activated alumina and bauxite samples are shown in Figures 2 and 3, where TGA curves show the total percent weight change of the samples as a function of temperature. In Figure 2, The TGA curves of spent activated alumina samples obtained from adsorption column runs at two different flow rates are presented, along with the TGA curve for fresh activated alumina sample. As can be seen from the figure, the TGA curve for the fresh alumina sample exhibited two plateaus corresponding to weight losses due to dehydration of water molecules (i.e physisorbed and chemisorbed water) from the alumina surface. The spent samples also showed two plateaus, but the weight loss due to desorption of activity-binding degradation products that were adsorbed from the solvent onto the alumina surface is significantly greater than water dehydration. The weight loss for the fresh activated alumina was approximately $12.5 \%$ total as compared to about $33.4 \%$ and $34.5 \%$ for spent alumina from adsorption runs at $1.7 \mathrm{ml} / \mathrm{min}$ and $2.5 \mathrm{ml} / \mathrm{min}$, respectively. It is important to note that a significant weight loss for the spent samples occured at temperature less than $200{ }^{\circ} \mathrm{C}$, where activity-binding degradation products would desorb or burn off to carbon dioxide and other volatile compounds. 
The TGA curves for spent activated bauxite samples are shown in Figure 3, along with the TGA curve for fresh bauxite sample; the spent samples were obtained from adsorption column runs at two different flow rates. The TGA curves for bauxite samples were similar to those of the activated alumina, showing two plateaus for both spent and fresh samples. The similarities of the TGA curves of the two adsorbents suggest that the same adsorption mechanism have taken place for activity-binding degradation products. The weight loss for the fresh activated bauxite was $12.6 \%$ total as compared to about $29.6 \%$ and $28.6 \%$ for the spent samples obtained from $1.45 \mathrm{ml} / \mathrm{min}$ and $2.2 \mathrm{ml} / \mathrm{min}$ adsorption runs, respectively. It should be noted that much of the weight loss for the spent samples again occured at temperatures lower than $200{ }^{\circ} \mathrm{C}$ as previously observed for the spent activated alumina samples.

Experimental Bearkthrough Curves: Experimental breakthrough curves of activity-binding degradation products on activated alumina and activated bauxite adsorbents are shown in Fig. 4, where the vertical axis represents the residual activity in effluent solvent in $\mathrm{dpm} / \mathrm{ml}$ and the horizontal axis represents the time elapsed from initial contact of contaminated solvent with the adsorbent bed. It should be noted that the same weight of adsorbents ( 50 g) was used in each case at ambient conditions. The feed flow rate was maintained at $0.7 \mathrm{ml} / \mathrm{min}$ for these experiments. As can be seen from the figure, a general similarity of the breakthrough curves exsits between Type A2, and Type RI samples. This suggests that the chemical nature of the active sites responsible for adsorption of degradation impurities on activated alumina is similar to that of activated bauxite. These sites are considered to 
be possessing both Lewis and Bronsted acidic sites which tend to adsorb organic compounds by chemisorption (10-11). The temperature effects on adsorption of activity-binding degradation products on activated alumina are shown in Figure 5. As shown in the figure, the residual activity in the effluent solvent decreases with increasing adsorption temperature, resulting in higher adsorption capacity of activated alumina. The temperature dependence of the present system is contrary to the physical adsorption phenomena in which higher adsorption temperatures will cause the adsorption capacity of the adsorbent to be reduced. Therefore, the adsorption of activity-binding degradation materials on activated alumina is more likely occuring by chemisorption mechanism. The chemisorption phenomena is considered specific and occurs only on certain active sites by covalent bonding or by ionic association. The adsorption capacity of the alumina at 24,42 , and $59{ }^{\circ} \mathrm{C}$ was found to be $1.05 \times 10^{4}, 1.86 \times 10^{4}$, and $1.80 \times 10^{4} \mathrm{dpm} / \mathrm{g}$, respectively. Table 3 shows that the calculated height of the adsorption zone decreases with increasing temperature and the efficiency increases. Figure 6 shows the effects of temperature on adsorption breakthrough curves of activity-binding degradation products on activated bauxite. As shown in the figure, the residual activity in the effluent solvent decreases with increasing temperature in the range from 26 to $69{ }^{\circ} \mathrm{C}$. The adsorption capacity of activated bauxite was found to be $1.92 \times 10^{5}, 1.96 \times 10^{5}$, and $2.04 \times 10^{5} \mathrm{dpm} / \mathrm{g}$ at 26,42 , and $69{ }^{\circ} \mathrm{C}$, respectively. In Table 4 , the calculated height and the efficiency of the adsorption zone are presented. Because different feed solvents and column sizes were used for activated alumina and bauxite systems, the merits of these results should be evaluated separately. 
The experimental breakthrough curves of activity-binding degradation products on activated alumina were obtained at three different feed flow rates, and the results are shown in Figure 7. As shown in the figure, the activity of the effluent solvent increases with increasing flow rate at breakthrough. In Table 5, however, the process dynamic parameters show a maximum column performance at $1.7 \mathrm{ml} / \mathrm{min}$, where the dynamic capacity of activated alumina is $1.28 \times 10^{4} \mathrm{dpm} / \mathrm{g}$ and the height and efficiency of the adsorption zone are $84.5 \mathrm{~cm}$ and $21.7 \%$, respevtively. Becuase the calculated height of the adsorption zone is nearly twice the adsorbent bed, additional quantity of adsorbent is required to compensate for the presence of the adsorption zone. Figure 8 shows the breakthrough curves of degradation products on activated bauxite at three different flow rates. The effects of the flow rate on the process dynamic parameters are shown in Table 6. As can be seen, the dynamic capacity of activated bauxite decreases with increasing flow rate in the expected direction. The calculated values were $1.37 \times 10^{5}$, $1.27 \times 10^{5}$, and $1.26 \times 10^{5} \mathrm{dpm} / \mathrm{g}$ for the flow rates $0.8,1.45$, and $2.1 \mathrm{ml} / \mathrm{min}$, respectively. The efficiency of the adsorption zone dropped from $62 \%$ to less than $40 \%$. Although these results show an expected trend, further optimization of the process operating parameters are needed for each particular waste solvent and adsorbent material.

\section{CONCLUSION}

An adsorption process was evaluated for decontamination of radioactive waste solvent from the Purex process. The process utilized two commercially available adsorbents for the removal of activity-binding degradation products from radioactive waste solvent. Experimental breakthrough curves were 
obtained from various column runs under wide range of operating temperatures and flow rates. The results from the experimental studies show the following:

1) The use of activated alumina and activated bauxite adsorbents can achieve the removal of activity-binding secondary degradation products from waste solvent in one-cycle process.

2) Thermogravimetric analysis of activated alumina and bauxite samples show similarity of adsorption mechanism for the two adsorbents.

3) The dynamic capacities of activated alumina and activated bauxite increase with adsorption temperature in the range from about $24^{\circ} \mathrm{C}$ to $70{ }^{\circ} \mathrm{C}$ and decrease with increasing feed flow rate.

4) The performance of the adsorption decontamination process can be correlated with experimental based process dynamic parameters.

\section{ACKNOWLEDGMENTS}

This work was supported by the U. S. Department of Energy Under Contract No. DE-AC09-89SR18035 with Westinghouse Savannah River Co. We gratefully acknowlege La Roche Chemicals for providing the activated bauxite samples and Engelhard Chemical Co. for providing the activated bauxite samples. We are indebted to Yvonne J. Simpkins and Kevin J. Kalbaugh for their assisstance in the experimental work. 


\section{REFERENCES}

1. E. S. Lane, Nucl. Sci. Eng., 17, 620 (1963).

2. J. C. Neace, Sep. Sci. Technol. 18, 1581 (1983).

3. O. K. Tallent, J. C. Mailen, and K. E. Dodson, Nucl. Technol. 71, 417 (1985).

4. Y. Sze, T. E. McDougall, and C. G. Martin, Solv. Extr.Ion Exch., 5(1), 129 (1987).

5. F. Secilio, T. H. Goodgame, and B. Wilkins, Nucl. Sci. Eng. 9, 455 (1961).

6. C. A. Blake, W. Davis, and J. M. Schmitt, Nucl. Sci. Eng. 17, 626 (1963).

7. D. J. Reif, Nucl. Technol., 83, 190 (1988).

8. J. C. Mailen, Nucl. Technol. 83, 182 (1988).

9. A. S. Michael. Ind. Eng. Chem. 44(8), 1922 (1952).

10. R. Desi, M. Hussein, and D. M. Ruthven, Can. J. Chem. Eng., 70, 699 (1992).

11. H. Tamon, S. Koyotani, and H. Wada, J. Chem. Eng. Japan, 14. 136 (1981). 


\section{List of Tables}

Table 1. Physico-Chemical Properties of Adsorbents

Table 2. Physico-Chemical Properties of n-paraffin diluent

Table 3. Effects of Temperature on Process Dynamic Parameters for Adsorption of Degradation Products on Activated Alumina

Table 4. Effects of Temperature on Process Dynamic Parameters for Adsorption of Degradation Products on Activated Bauxite

Table 5. Effects of Flow Rate on Process Dynamic Parameters for Adsorption of Degradation Products on Activated Alumina

Table 6. Effects of Flow Rate on Process Dynamic Parameters for Adsorption of Degradation Products on Activated Bauxite 


\section{LIST OF FIGURES}

Figure 1. Schematic diagram of experimental apparatus

Figure 2. TGA weight loss curves of activated alumina samples

Figure 3. TGA weight loss curves of activated bauxite samples

Figure 4. Experimental breakthrough curves of degradation products on activated alumina and bauxite samples

Figure 5. Temperature effects on adsorption of degradation products on activated alumina

Figure 6. Temperature effects on adsorption of degradation products on activated bauxite

Figure 7. The effects of flow rate on breakthrough curves of degradation products on activated alumina

Figure 8. The effects of flow rate on breakthrough curves of degradation products on activated bauxite 
Table 1. Physico-Chemical Properties of Adsorbents (data from manufacturers)

\begin{tabular}{|c|c|c|}
\hline Properties & Activated Alumina & Activated Bauxite \\
\hline Composition, wt $\%$ & & \\
$\mathrm{Al}_{2} \mathrm{O}_{3}$ & 93.6 & 77.7 \\
$\mathrm{SiO}_{2}$ & 0.02 & 10.8 \\
$\mathrm{~F}_{2} \mathrm{O}_{3}$ & 0.02 & 6.5 \\
$\mathrm{TiO}_{2}$ & 0.002 & 5.0 \\
$\mathrm{Na} 2 \mathrm{O}$ & 0.35 & - \\
\hline Particle size, $\mathrm{mesh}$ & $12 \times 32$ & $30 \times 60$ \\
\hline Bulk density, $\mathrm{kg} / \mathrm{m}^{3}$ & 675 & 853 \\
\hline surface area, $\mathrm{m}^{2} / \mathrm{g}$ & 310 & 244.08 \\
\hline
\end{tabular}


Table 2. Physico-Chemical Properties of n-paraffin diluent

\begin{tabular}{|c|c|}
\hline Property & n-Paraffin $\left(\mathrm{C}_{11}-\mathrm{C}_{16}\right)$ \\
\hline \multicolumn{2}{|l|}{ Composition } \\
\hline $\mathrm{n}$ - paraffin, wt $\%$ & 98 \\
\hline aromatics, $\mathrm{wt}^{\%} \%$ & 0.2 \\
\hline olefins, wt $\%$ & 0.1 \\
\hline Flash point, ${ }^{\circ} \mathrm{C}, \mathrm{min}$. & 70 \\
\hline Sp. gravity, $25 / 25^{\circ} \mathrm{C}, \max$ & 0.77 \\
\hline Viscosity, $\mathrm{Cp}, 25^{\circ} \mathrm{C}, \max$ & 2.0 \\
\hline Disengaging time, sec & \\
\hline (70\%n-paraffin, $30 \%$ TBP) & \\
\hline $1 \mathrm{M} \mathrm{NaOH}$, sec., $\max$ & 80 \\
\hline $1 \mathrm{M}$ HNO3, sec. $\max$. & 50 \\
\hline Color & colorless \\
\hline
\end{tabular}


Table 3. Effects of Temperature on Process Dynamic Parameters for Adsorption of Degradation Products on Activated Alumina.

\begin{tabular}{|cccc|}
\hline $\begin{array}{c}\text { temperature } \\
\left({ }^{\circ} \mathrm{C}\right)\end{array}$ & $\begin{array}{c}\text { height of adsorption } \\
\text { zone }\left(\mathrm{h}_{\mathrm{z}, \mathrm{cm}}\right)^{*}\end{array}$ & $\begin{array}{c}\text { efficiency }(\gamma, \%) \text { of } \\
\text { adsorption zone }\end{array}$ & $\begin{array}{c}\text { dynamic capacity } \\
\left(\mathrm{q}_{\mathrm{m}} \mathrm{dpm} / \mathrm{g} \text { adsorbent }\right)\end{array}$ \\
\hline 24 & 95.5 & 11.6 & $1.05 \times 10^{4}$ \\
42 & 85.9 & 20.5 & $1.86 \times 10^{4}$ \\
59 & 59.9 & 44.6 & $1.80 \times 10^{4}$ \\
\hline
\end{tabular}

* based on total bed height of $43.7 \mathrm{~cm}$ with column diameter of $13 \mathrm{~mm}$ 
Table 4. Effects of Temperature on Process Dynamic Parameters for Adsorption of Degradation Products on Activated Bauxite

\begin{tabular}{|cccc|}
\hline $\begin{array}{c}\text { temperature } \\
\left({ }^{\circ} \mathrm{C}\right)\end{array}$ & $\begin{array}{c}\text { height of adsorption } \\
\text { zone }\left(\mathrm{h}_{\mathrm{z}, \mathrm{cm}}\right)^{*}\end{array}$ & $\begin{array}{c}\text { efficiency }(\gamma, \%) \text { of } \\
\text { adsorption zone }\end{array}$ & $\begin{array}{c}\text { dynamic capacity } \\
\left(\mathrm{q}_{\mathrm{m}} \mathrm{dpm} / \mathrm{g} \text { adsorbent }\right)\end{array}$ \\
\hline 26 & 19.6 & 65.8 & $1.92 \times 10^{5}$ \\
42 & 24.1 & 57.8 & $1.96 \times 10^{5}$ \\
69 & 23.1 & 59.5 & $2.04 \times 10^{5}$ \\
\hline
\end{tabular}

* based on total bed height of $22.9 \mathrm{~cm}$ with column diameter of $25 \mathrm{~mm}$. 
Table 5. Effects of Flow Rate on Process Dynamic Parameters for Adsorption of Degradation Products on Activated Alumina

\begin{tabular}{|cccc|}
\hline $\begin{array}{c}\text { flow rate } \\
(\mathrm{ml} / \mathrm{min})\end{array}$ & $\begin{array}{c}\text { height of adsorption } \\
\text { zone }\left(\mathrm{h}_{\mathrm{z}, \mathrm{cm}}\right)^{*}\end{array}$ & $\begin{array}{c}\text { efficiency }(\gamma, \%) \text { of } \\
\text { adsorption zone }\end{array}$ & $\begin{array}{c}\text { dynamic capacity } \\
\left(\mathrm{q}_{\mathrm{m}} \mathrm{dpm} / \mathrm{g} \text { adsorbent }\right)\end{array}$ \\
\hline 0.7 & 88.0 & 18.5 & $6.65 \times 10^{3}$ \\
1.7 & 84.5 & 21.7 & $1.28 \times 10^{4}$ \\
2.5 & 93.8 & 13.2 & $7.02 \times 10^{3}$ \\
\hline
\end{tabular}

* based on total bed height of $43.7 \mathrm{~cm}$ with column diameter of $13 \mathrm{~mm}$ 
Table 6. Effects of Flow Rate on Process Dynamic Parameters for Adsorption of Degradation Products on Activated Bauxite

\begin{tabular}{|cccc|}
\hline $\begin{array}{c}\text { flow rate } \\
(\mathrm{ml} / \mathrm{min})\end{array}$ & $\begin{array}{c}\text { height of adsorption } \\
\text { zone }\left(\mathrm{h}_{\mathrm{z}, \mathrm{cm}}\right)^{*}\end{array}$ & $\begin{array}{c}\text { efficiency }(\gamma, \%) \text { of } \\
\text { adsorption zone }\end{array}$ & $\begin{array}{c}\text { dynamic capacity } \\
\left(\mathrm{q}_{\mathrm{m}} \mathrm{dpm} / \mathrm{g} \text { adsorbent }\right)\end{array}$ \\
\hline 0.8 & 21.3 & 62.5 & $1.37 \times 10^{5}$ \\
1.45 & 35.1 & 38.5 & $1.27 \times 10^{5}$ \\
2.1 & 33.3 & 41.9 & $1.26 \times 10^{5}$ \\
\hline
\end{tabular}

* based on total bed height of $22.9 \mathrm{~cm}$ with column diameter of $25 \mathrm{~mm}$. 


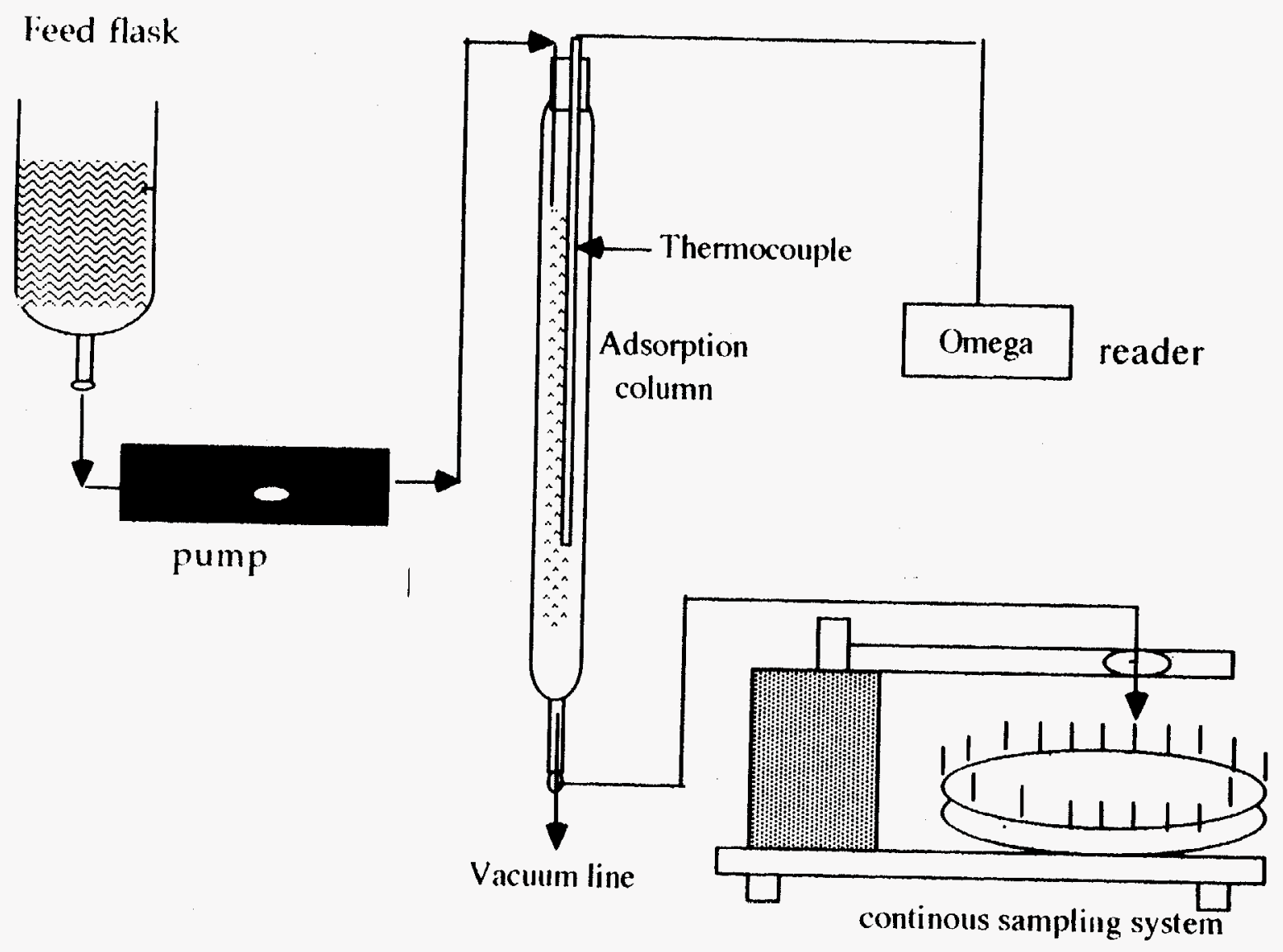

Figure 1. Schematic diagram of the experimental apparatus 


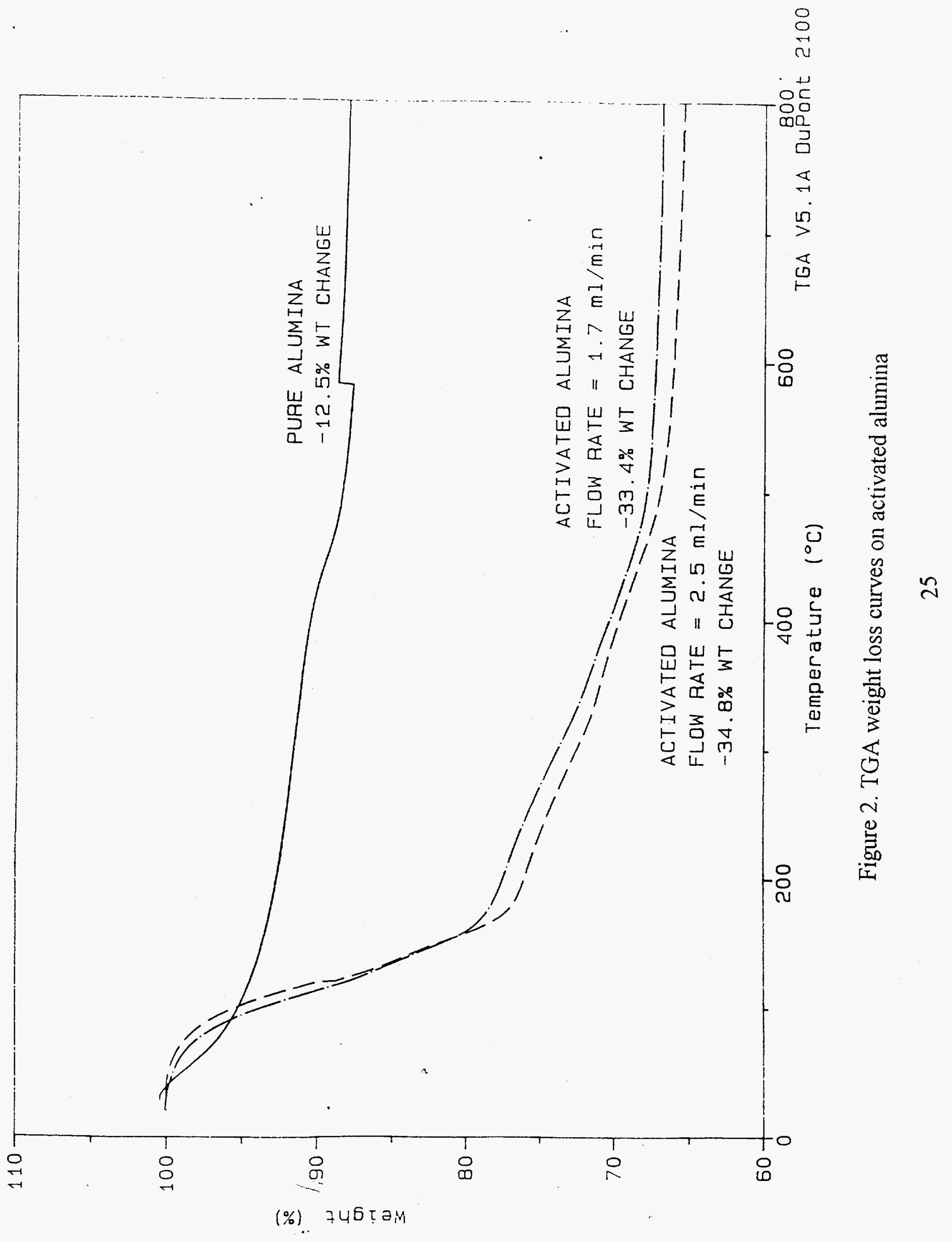




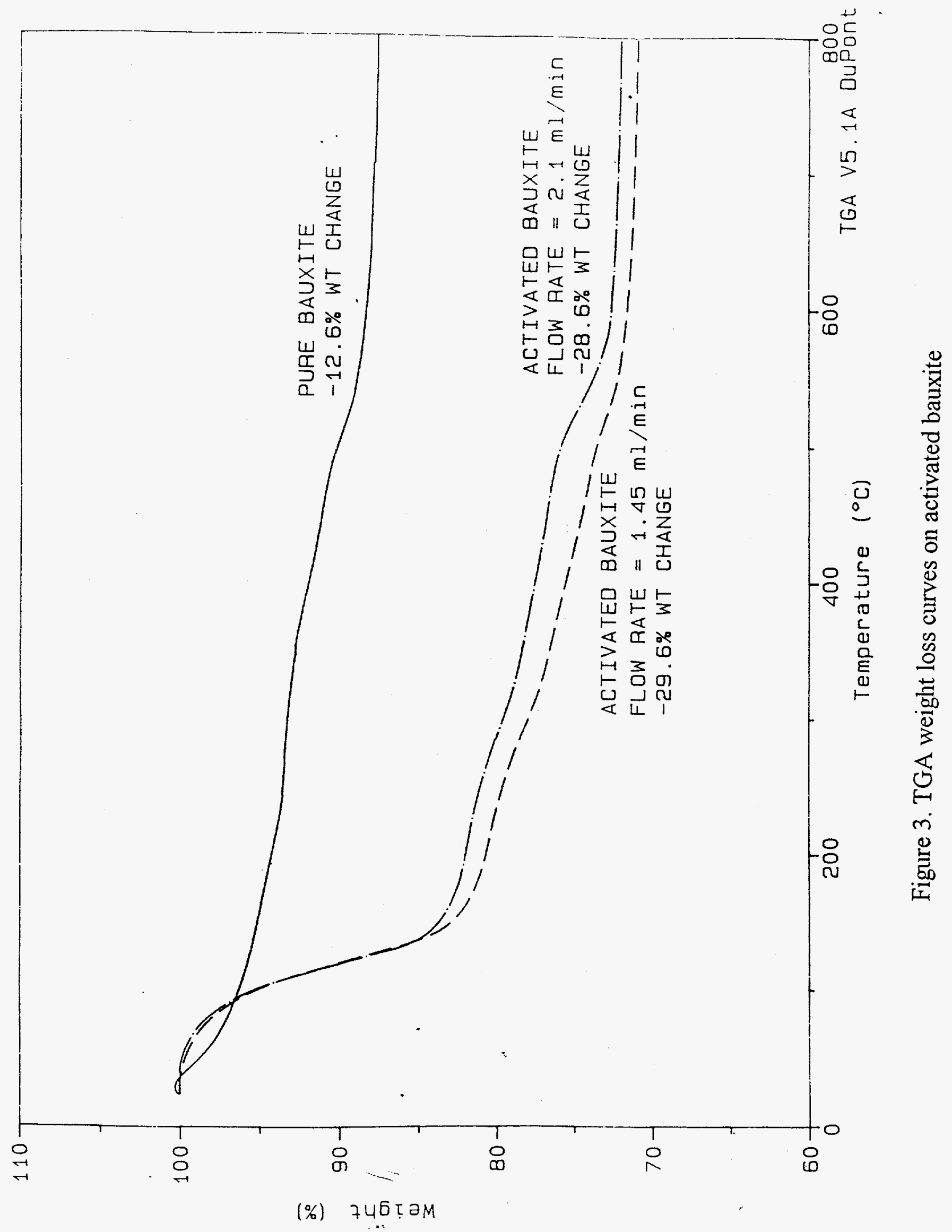




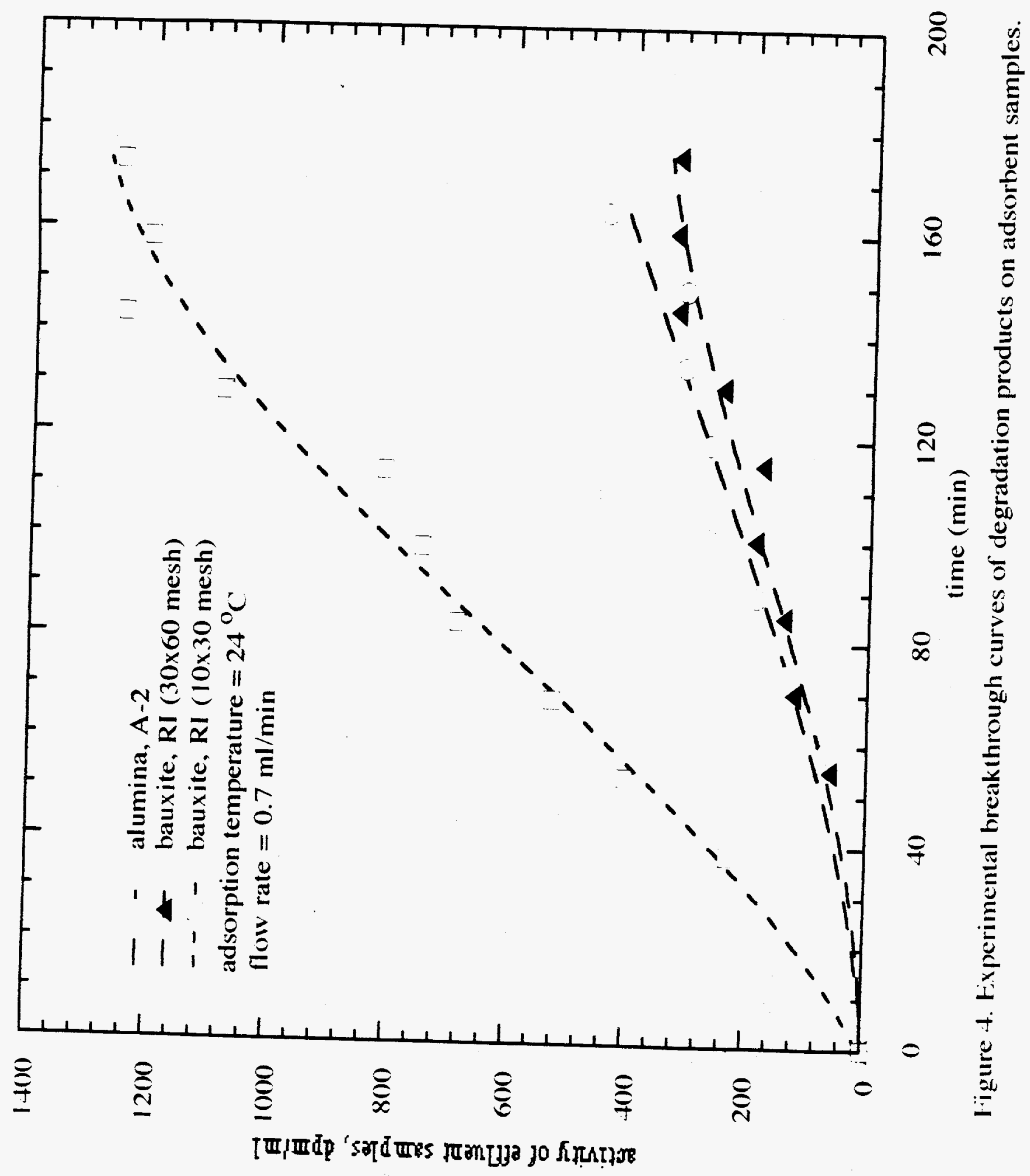




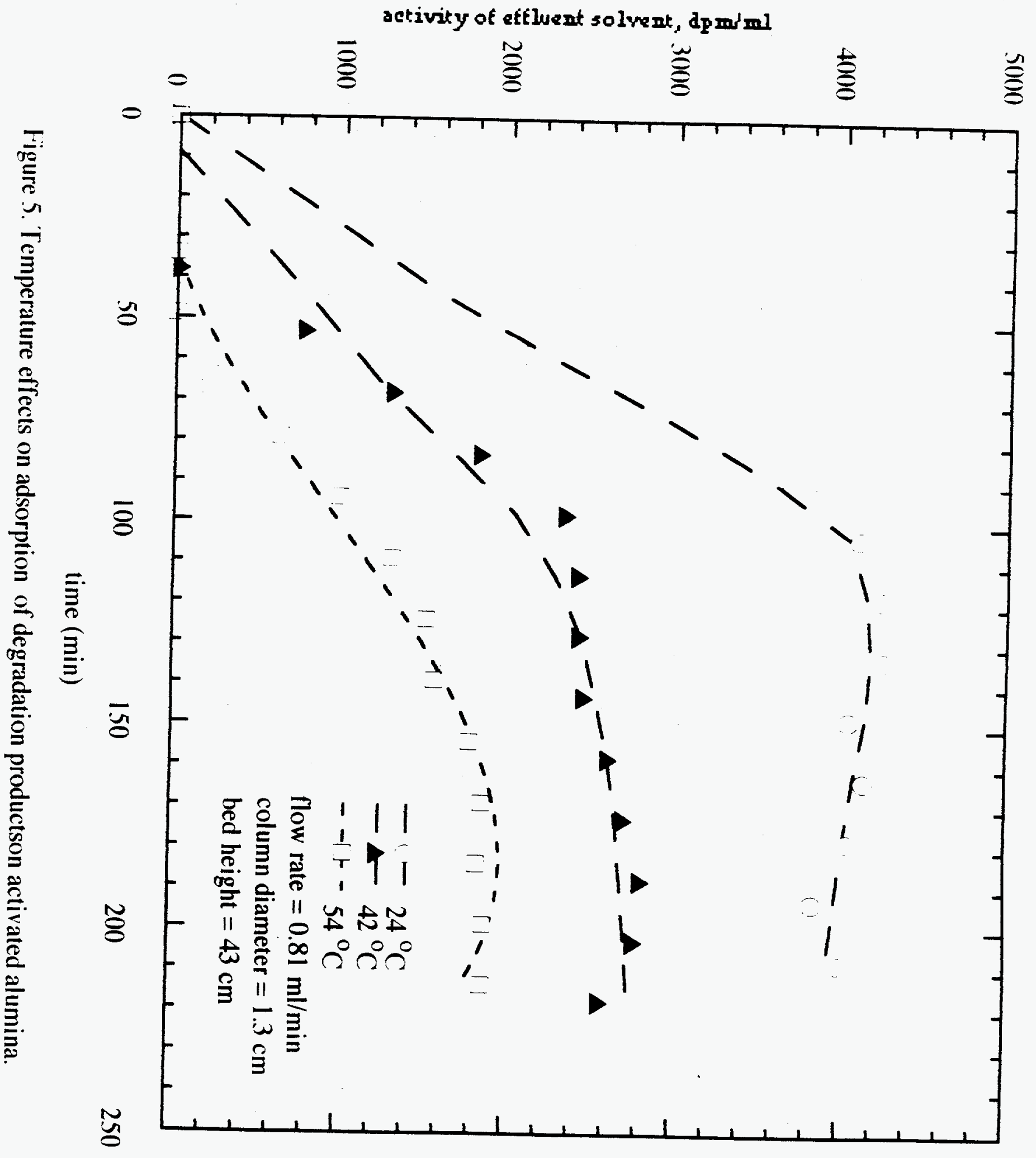




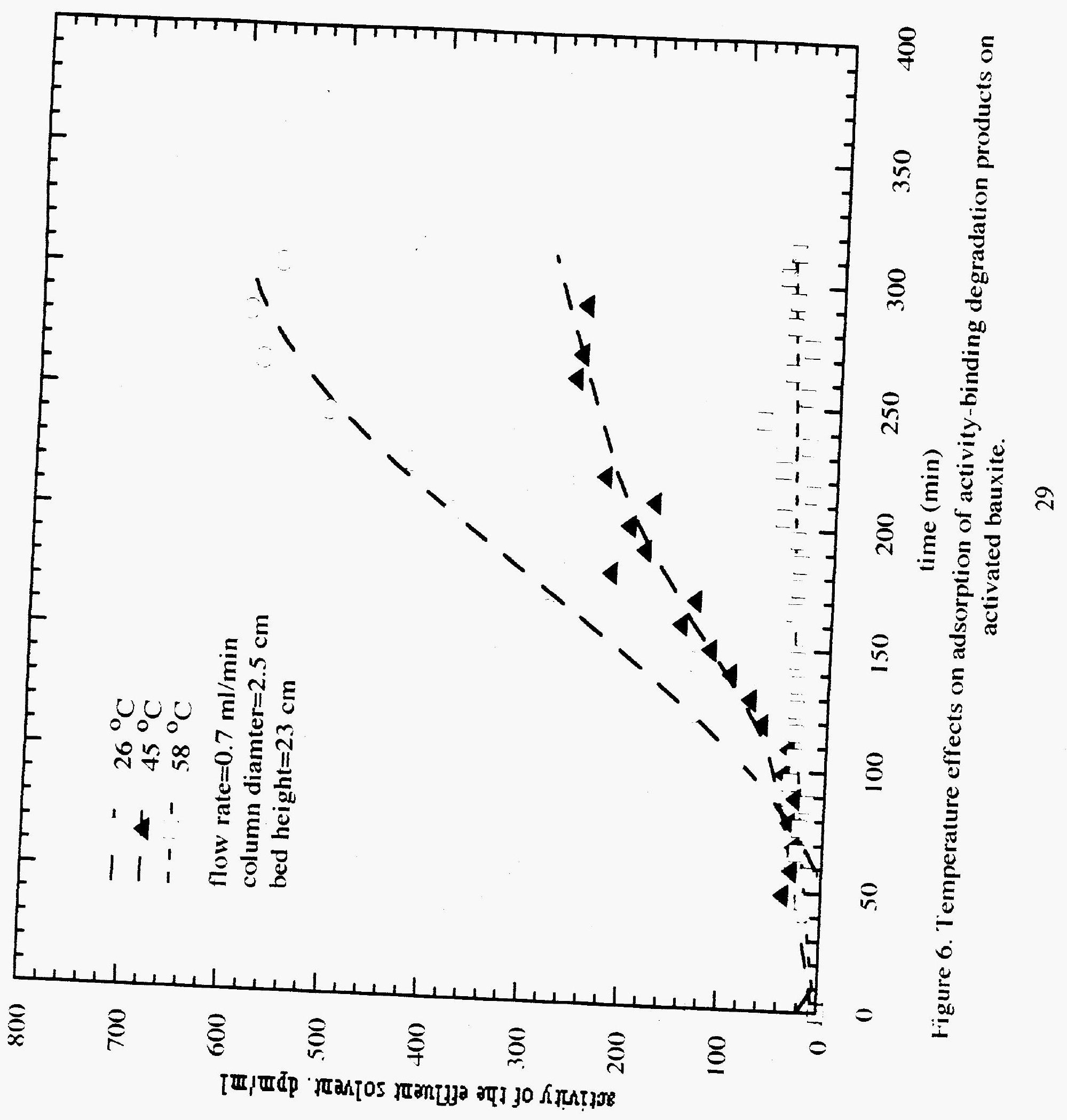




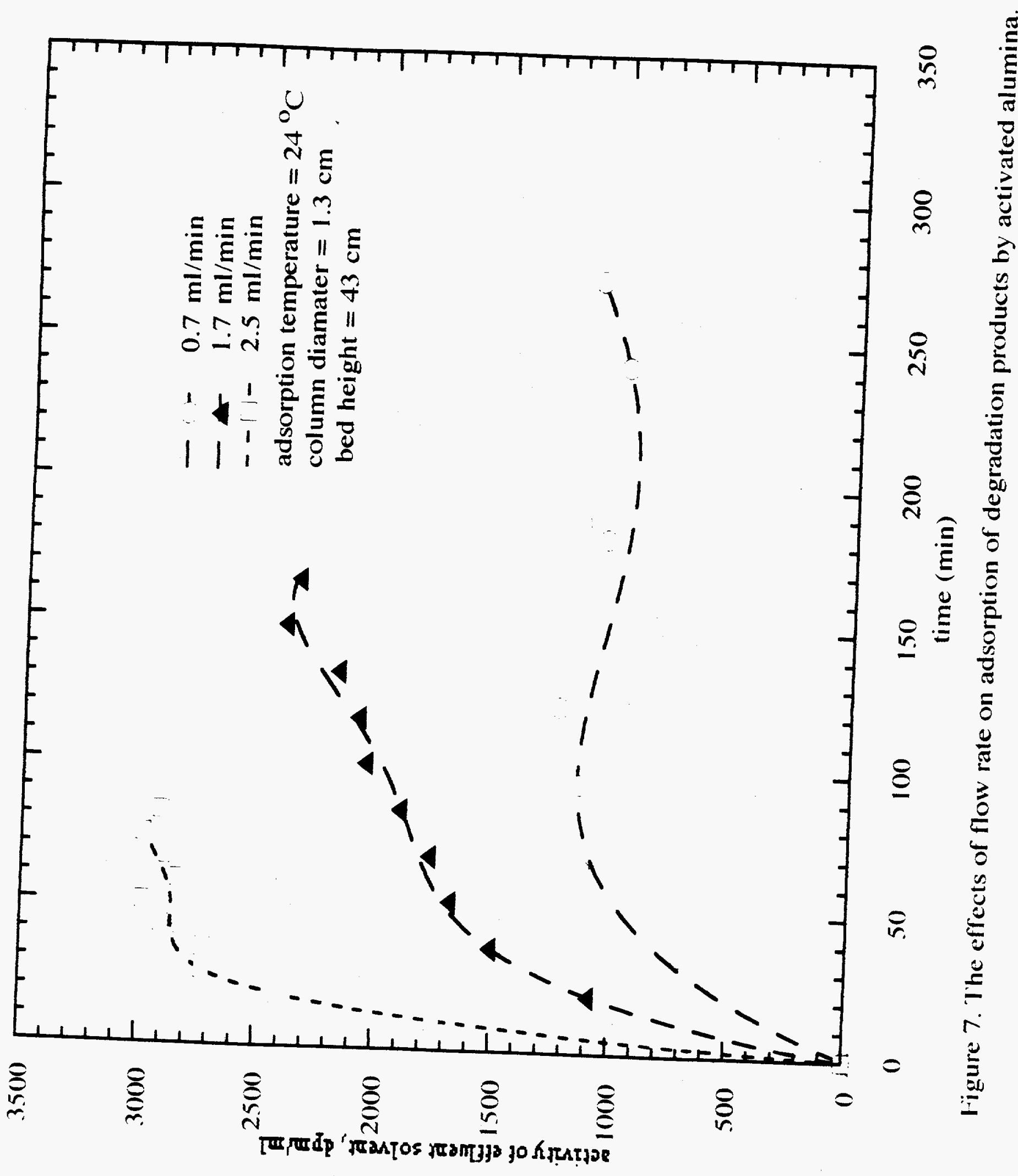




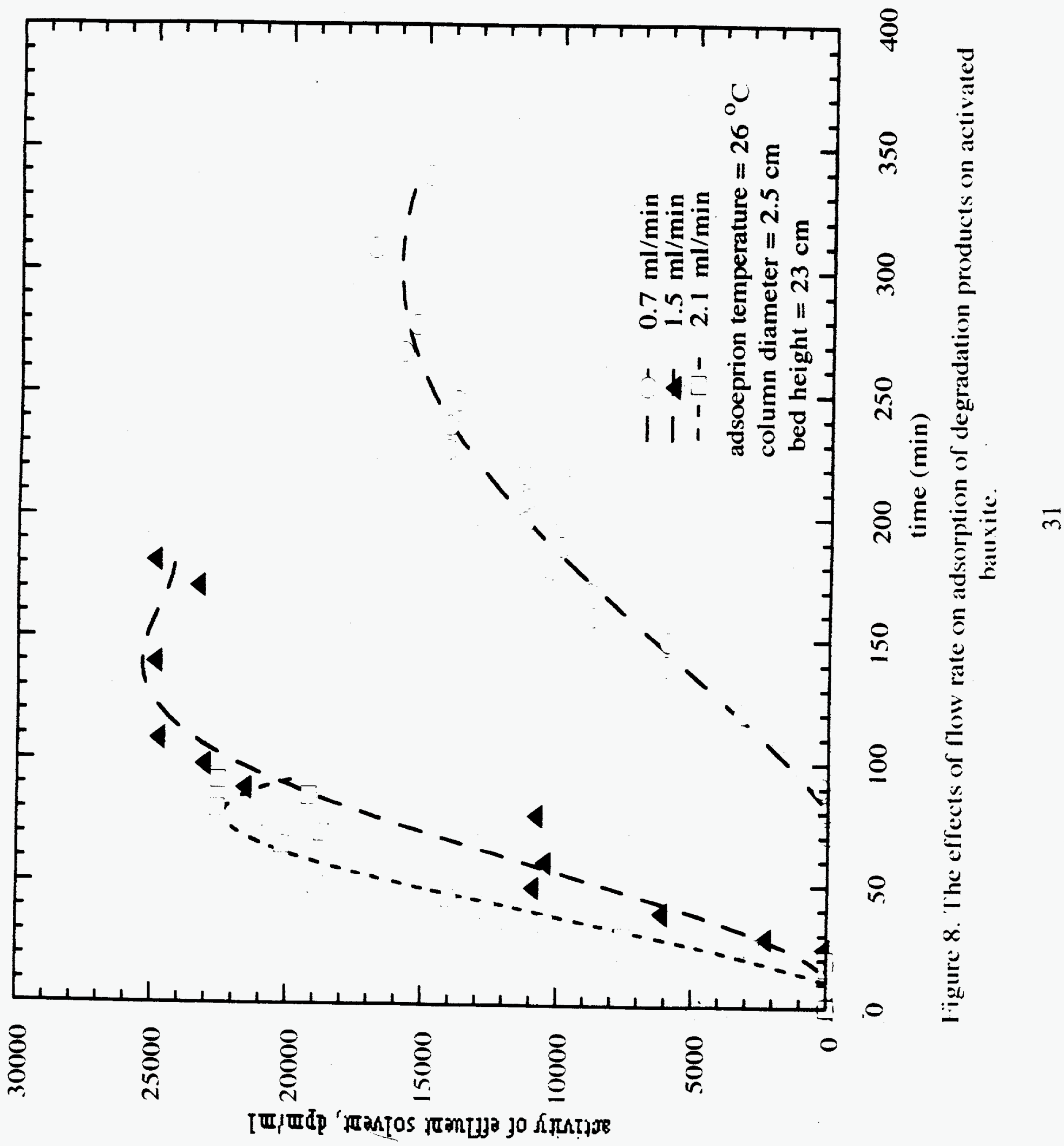

